\title{
Perilaku Campuran Semen dan Fly Ash sebagai Bahan Dasar Mortar Instant untuk Pemasangan Keramik Dinding
}

\author{
The Behavior of Cement and Fly Ash Mixed \\ as Basic Materials for Instant Mortar
}

\author{
Munafri Alwys, Sudaryono \\ Jurusan Teknik Sipil, Politeknik Negeri Padang \\ Telp. 0751-72590 Fax.0751-72576 Email : wysesa@ gmail.com
}

\begin{abstract}
Steam Electrics Power Sijantang Sawahlunto in West Sumatra, produce fly ash waste from coal burning which is very much every day (about 300 tons/day). Air pollution caused by fly-ash has been disturbing the community surrounding due to environmental pollution, the pollution has been carried away by water flown to the rice fields, causing the rice crops of community are damage. It is already a big problem, because the public has repeatedly protested to the PLN, even the local government had been repeatedly requested to the PLN, to resolved that the issue soon.

To solved that problem, PLN in cooperation with Padang State of Polytechnic, has done some research in order to utilize the waste fly ash into building materials. The results of this study prove that the waste fly ash can be used as the basic material to produce instant tiling mortar. Through research conducted, it is found a smart way out, where "there is a problem that can be used as an opportunity" especially if people are trained and given the opportunity to produce mortar instant in their homes (home industry), it will be able to improve the economy and welfare of the people around the plant Sijantang.
\end{abstract}

Keywords: power plant, fly ash, pollution, instant mortar

\section{PENDAHULUAN}

Fly ash dan bottom ash merupakan limbah padat yang dihasilkan dari pembakaran batubara pada pembangkit tenaga listrik. Ada tiga type pembakaran batubara pada industri listrik yaitu dry bottom boilers, wet-bottom boilers dan cyclon furnace. Sri Prabandiyani Retno Wardani (Desember.2008) menjelaskan bahwa apabila batubara dibakar dengan type dry bottom boiler, maka kurang lebih $80 \%$ dari abu meninggalkan pembakaran sebagai fly ash dan masuk dalam corong gas, dan jika batubara dibakar dengan wetbottom boiler sebanyak $50 \%$ dari abu tertinggal di pembakaran dan 50\% lainnya masuk dalam corong gas. Pada system cyclon furnace, dimana potongan batubara digunakan sebagai bahan bakar, 70-80 \% dari abu tertahan sebagai boiler slag dan hanya $20-30 \%$ meninggalkan pembakaran sebagai dry ash pada corong gas.
Jika Fly ash dan bottom ash ini terdapat dalam jumlah yang cukup besar, dapat menimbulkan masalah lingkungan, seperti pencemaran udara, atau perairan, dan penurunan kualitas ekosistem. Seperti yang terjadi pada Pembangkit Listrik Tenaga Uap Sijantang Sawahlunto di Sumatera Barat, limbah abu terbang batu bara (fly ash) cukup banyak bahkan sudah mengganggu lingkungan akibat polusi udara, sehingga mencemari sawah-sawah penduduk di sekitarnya. Salah satu satu jalan penanganan lingkungan yang dapat diterapkan adalah dengan cara memanfaatkan limbah fly ash untuk keperluan bahan bangunan teknik sipil.

Fly ash dan bottom ash merupakan limbah padat yang dihasilkan dari pembakaran batubara pada pembangkit tenaga listrik. Ada tiga type pembakaran batubara pada industri listrik yaitu $d r y$ bottom boilers, wet-bottom boilers dan 
cyclon furnace. Sri Prabandiyani Retno Wardani (Desember.2008) menjelaskan bahwa apabila batubara dibakar dengan type dry bottom boiler, maka kurang lebih $80 \%$ dari abu meninggalkan pembakaran sebagai fly ash dan masuk dalam corong gas, dan jika batubara dibakar dengan wetbottom boiler sebanyak $50 \%$ dari abu tertinggal di pembakaran dan 50\% lainnya masuk dalam corong gas. Pada system cyclon furnace, dimana potongan batubara digunakan sebagai bahan bakar, 70-80 \% dari abu tertahan sebagai boiler slag dan hanya $20-30 \%$ meninggalkan pembakaran sebagai dry ash pada corong gas. Type yang paling umum untuk pembakaran batubara adalah pembakaran dry bottom.

Jika Fly ash dan bottom ash ini terdapat dalam jumlah yang cukup besar, dapat menimbulkan masalah lingkungan, seperti pencemaran udara, atau perairan, dan penurunan kualitas ekosistem. Seperti yang terjadi pada Pembangkit Listrik Tenaga Uap (PLTU) Sijantang Sawahlunto di Sumatera Barat, limbah abu terbang batu bara (fly ash) cukup banyak bahkan sudah mengganggu lingkungan akibat polusi udara, sehingga mencemari sawah-sawah penduduk di sekitarnya. Salah satu satu jalan penanganan lingkungan yang dapat diterapkan adalah dengan cara memanfaatkan limbah fly ash untuk keperluan bahan bangunan teknik sipil.

\section{Kandungan dan Kelas Fly Ash}

Fly ash merupakan material yang memiliki ukuran butiran yang halus, berwarna keabu-abuan dan diperoleh dari hasil pembakaran batubara (lihat Gambar 2). Pada intinya fly ash mengandung unsur kimia antara lain silika ( $\mathrm{SiO} 2)$, alumina (Al2O3), fero oksida (Fe2O3) dan kalsium oksida $(\mathrm{CaO})$, juga mengandung unsur tambahan lain yaitu magnesium oksida $(\mathrm{MgO})$, titanium oksida (TiO2), alkalin (Na2O dan K2O), sulfur trioksida (SO3), pospor oksida (P2O5) dan carbon. Faktorfaktor yang mempengaruhi sifat fisik, kimia dan teknis dari fly ash adalah tipe batubara, kemurnian batubara, tingkat penghancuran, tipe pemanasan dan operasi, metoda penyimpanan dan penimbunan. Adapun komposisi kimia dan klasifikasinya seperti dapat dilihat pada Tabel 1.

Tabel 1. Komposisi dan Klasifikasi Fly ash

\begin{tabular}{|c|c|c|c|}
\hline Komponen (\%) & Bituminus & Subbitumins & Lignit \\
\hline $\mathrm{SiO} 2$ & $20-60$ & $40-60$ & $15-45$ \\
\hline $\mathrm{Al} 2 \mathrm{O} 3$ & $5-35$ & $20-30$ & $20-25$ \\
\hline $\mathrm{Fe} 2 \mathrm{O} 3$ & $10-40$ & $4-10$ & $4-15$ \\
\hline $\mathrm{CaO}$ & $1-12$ & $5-30$ & $15-40$ \\
\hline $\mathrm{MgO}$ & $0-5$ & $1-6$ & $3-10$ \\
\hline $\mathrm{SO} 3$ & $0-4$ & $0-2$ & $0-10$ \\
\hline $\mathrm{Na} 2 \mathrm{O}$ & $0-4$ & $0-2$ & $0-6$ \\
\hline $\mathrm{K} 2 \mathrm{O}$ & $0-3$ & $0-4$ & $0-4$ \\
\hline LOI & $0-15$ & $0-3$ & $0-5$ \\
\hline
\end{tabular}

(Sumber Sri Prabandiyani Retno Wardani (Desember.2008)

Menurut ASTM C618 fly ash dibagi menjadi dua, yaitu fly ash kelas F dan kelas C. Perbedaan utama dari kedua fly ash tersebut adalah banyaknya calsium, silika, aluminium dan kadar besi di fly ash tersebut. Walaupun kelas $\mathrm{F}$ dan kelas $\mathrm{C}$ sangat ketat ditandai untuk digunakan fly ash yang memenuhi spesifikasi ASTM 
C618, namun istilah ini lebih umum digunakan berdasarkan asal produksi batubara atau kadar $\mathrm{CaO}$. Yang penting diketahui, bahwa tidak semua fly ash dapat memenuhi persyaratan ASTM C618, kecuali pada aplikasi untuk beton, persyaratan tersebut harus dipenuhi.

Fly ash kelas F: merupakan fly ash yang diproduksi dari pembakaran batu bara anthracite atau bituminous, mempunyai sifat pozzolanic dan untuk mendapatkan sifat cementitious harus diberi penambahan quick lime, hydrated lime, atau semen. Fly ash kelas $\mathrm{F}$ ini kadar kapurnya rendah $(\mathrm{CaO}$ $<10 \%)$.

Fly ash kelas C: diproduksi dari pembakaran batubara lignite atau subbituminous selain mempunyai sifat pozolanic juga mempunyai sifat selfcementing (kemampuan untuk mengeras dan menambah strength apabila bereaksi dengan air) dan sifat ini timbul tanpa penambahan kapur. Biasanya mengandung kapur $(\mathrm{CaO})>20 \%$.

\section{METODOLOGI}

Ada tiga metoda yang dilakukan dalam penelitian fly ash ini, yaitu mulai dari melakukan studi literature. Studi literatur dimaksudkan untuk mendapatkan masukan tentang dasar-dasar dari campuran mortar yang terbuat dari fly ash ditambah semen. Sedangkan pengujian properties fly ash dilakukan melalui pengujian di laboratorium yang meliputi pengujian berat isi, berat jenis, kadar air dan analisa saringan fly ash. Selanjutnya penelitian perilaku campuran mortar dalam beberapa komposisi campuran yang mencakup, pengujian kuat tekan kubus mortar, pengujian waktu ikat (setting time), pengujian daya lengket mortar terhadap keramik, dan pengaruh terhadap pemuaian dan penyusutan, dilakukan pada laboratorium Teknik Sipil Politeknik
Negeri Padang. Lokasi penelitian ada pada dua tempat yakni di Laboratorium Teknik Sipil PNP dan di lokasi PLTU Sijantang Sawahlunto.

Ada 4 tahapan yang dilalui dalam penelitian pemanfaatan fly ash sebagai bahan dasar mortar instan untuk pemasangan keramik ini yaitu ;

\section{Pengambilan bahan sampel di PLTU Sijantang}

Sebanyak 1 colt diesel fly ask diambil di PLTU Sijantang dan dibawa ke Laboratorium Teknik Sipil Politeknik Negeri Padang. Sedangkan semen yang digunakan semen type PCC produksi Semen Padang.

\section{Study Literatur}

Bebarapa jurnal hasil penelitian yang pernah dilakukan oleh para pakar tentang penelitian fly ash dipelajari, dan beberapa temuan dan statemen mereka dikutip guna memperkuat hasil penelitian ini.

\section{Pengujian properties fly ash}

Pengujian ini dilakukan menggunakan peralatan yang tersedia pada laboratorium Teknik Sipil PNP. Penelitian ini mencakup nilai berat isi, berat jenis, kadar air serta analisa saringan.

\section{Penelitian perilaku mortar campuran semen + fly ash}

Mortar hasil campuran semen + fly ash dilakukan pengujian, baik dalam kondisi masih plastis, maupun setelah mengeras. Dalam kondisi mortar masih plastis dilakukan pengujian waktu ikat (setting time) adonan mortar. Sedang setelah mortar mengeras dilakukan pengujian kuat tekan, mulai umur 3 hari, 7 hari, 14 hari sampai umur 28 hari.

Pengujian ini mencakup kuat tekan kubus mortar, daya lengket mortar terhadap keramik, pengaruh pemuaian dan penyusutan terhadap ikatan mortar dan keramik. 


\section{Flowchart Kegiatan Penelitian}

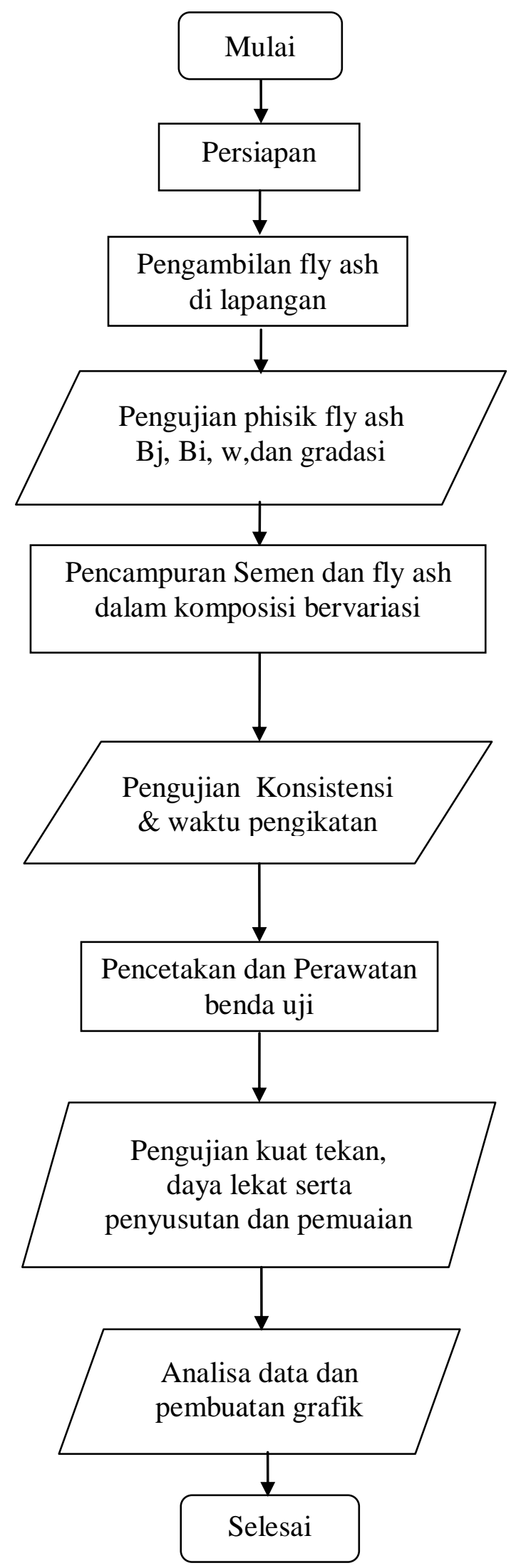


HASIL

Berdasarkan pengujian-pengujian properties fly ash batu bara yang dilakukan di laboratorium Teknik Sipil Politeknik
Negeri Padang diperoleh nilai karakteristik fly ash limbah PLTU Sijantang sebagai berikut;

\section{Berat Isi}

Tabel 2. Berat Isi Fly Ash PLTU Sawahlunto

\begin{tabular}{|c|c|c|c|}
\hline \multirow{2}{*}{ Berat (gram) } & W1 (gram) & W2 (gram) & W3 (gram \\
\cline { 2 - 4 } & 74,65 & 69,59 & 72,42 \\
\hline Wrata-rata (gram) $=$ & \multicolumn{3}{|c|}{72,22} \\
\hline & & & \\
\hline Vol.wadah $(\mathrm{Cm} 3)=$ & \multicolumn{3}{|c|}{95,22} \\
\hline & & & \\
\hline Berat Isi (Yi) & $=\mathrm{Wr} /$ Vol. & $=72,22 / 95,22$ & $\mathbf{0 , 7 6} \mathbf{~ g r} / \mathbf{c m} 3$ \\
\hline
\end{tabular}

\section{Berat Jenis}

Tabel 3. Berat Jenis Fly Ash PLTU Sawahlunto

\begin{tabular}{|l|l|r|r|r|}
\hline \multicolumn{1}{|c|}{ Piknometer No. } & \multicolumn{1}{|c|}{ Simbol/Formula } & \multicolumn{1}{c|}{$\mathbf{1}$} & \multicolumn{1}{c|}{$\mathbf{2}$} \\
\hline Berat Piknometer & (W1) gr. & 40,86 & 38,47 & 41,05 \\
\hline Berat Piknometer + Fly ash & (W2) gr. & 67,00 & 63,47 & 66,22 \\
\hline Berat Fly ash & WF = (W2-W1) gr. & 27,86 & 25,00 & 25,17 \\
\hline Berat Piknometer + Fly ash + air & (W3) gr. & 153,45 & 151,00 & 153,85 \\
\hline Berat piknometer + air & (W4) gr. & 140,50 & 138,49 & 141,38 \\
\hline Temperatur & (o C) & 25,00 & 25,00 & 25,00 \\
\hline Faktor Koreksi Temperatur & (K) & 1,00 & 1,00 & 1,00 \\
\hline $\begin{array}{l}\text { Berat Piknometer + air } \\
\text { terkoreksi }\end{array}$ & (W5) gr. & 140,50 & 138,49 & 141,38 \\
\hline Berat Jenis Fly Ash & (W2-W1)/[(W5-W1)-(W3-W2)] & 2,06 & 2,01 & 1,98 \\
\hline \multicolumn{2}{|r|}{ Berat Jenis Rata-Rata } & $\mathbf{2 , 0 2}$ \\
\hline
\end{tabular}




\section{Kadar Air}

Tabel 4. Kadar Air Fly Ash PLTU Sawahlunto

\begin{tabular}{|c|c|c|c|}
\hline No. Cawan & $\mathbf{1}$ & 2 & 3 \\
\hline Berat Cawan & 16,14 & 16,30 & 16,22 \\
\hline Berat Cawan + Fly ash & 62,72 & 61,88 & 62,30 \\
\hline Berat Cawan + Fly ash kering (W3) gr. & 62,55 & 61,78 & 62,17 \\
\hline$(\mathrm{W} 2-\mathrm{W} 3) \mathrm{gr}$. & 0,17 & 0,10 & 0,13 \\
\hline Berat Fly ash kering & 46,41 & 45,48 & 45,95 \\
\hline Kadar Air & 0,36 & 0,22 & 0,29 \\
\hline Kadar air rata-rata & \multicolumn{3}{|c|}{0,29} \\
\hline
\end{tabular}

Untuk mengetahui kemampuan mortar campuran semen dan fly ash, dibuat beberapa komposisi campuran mortar baik dalam perbandingan volume maupun dalam perbandingan berat, lalu dilakukan pengujian kuat tekan, waktu ikat, daya lengket serta pengaruh dari pemuaian dan penyusutan terhadap hubungan mortar dan keramik. Dari berbagai macam pengujian tersebut diperoleh hasilnya sebagai berikut ;

\section{Analisa Saringan}

Untuk melihat gradasi butiran dilakukan uji saringan fly ash, mulai dari saringan nomor 6 s/d dengan nomor 200 . Dari hasil uji saringan ini ternyata semua butiran fly ash lolos saringan nomor 200 . Maka dapat dikategorikan bahwa fly ash termasuk butiran berbutir halus.

\section{Pengujian Kuat Tekan Kubus Mortar}

Pengujian kuat tekan beton ditujukan untuk mengetahui kemampuan mortar yang sudah mengeras memikul beban diatasnya, pengujian ini dilakukan dengan langkahlangkah sebagai berikut ;

1) Buat campuran semen dan fly ash dalamn perbandingan tertentu, baik dalam perbandingan volume maupun perbandingan berat.

2) Kemudian siapkan cetakan kubus mortar ukuran $5 \times 5 \times 5 \mathrm{~cm}$ sebanyak yang diperlukan.
3) Kemudian tambahkan air sebanyak $6 \%$ kedalam campuran bahan tadi, lalu diaduk sampai homogen dan plastis.

4) Setelah itu adukan mortar tersebut dimasukan kedalam cetakan, pertama setengah tinggi cetakan, lalu dipadatkan dengan jalan menusuknusuk pakai stik besi sampai padat, kemudian diisikan mortar setengah lagi lalu dipadatkan sampai rata permukaan cetakan, terus diratakan.

5) Mortar yang sudah berada dalam cetakan tersebut diletakkan ditempat yang aman.

6) Kemudian dilakukan curing dengan jalan merendam kubus mortar dalam air.

7) Setelah berumur tiga hari lalu kubus mortar dikeluarkan dari cetakan, langsung 2 buah kubus diuji tekan guna mengetahui kuat tekannya.

8) Terus berturut-turut umur 7 hari, umur 14 hari, umur 21 hari dan umur 28 hari dilakukan uji tekan kubus mortar tersebut.

9) Data hasil pengukuran tersebut ditabelkan, kemudian dianalisa guna mendapatkan nilai kuat tekan rata-rata setiap umur kubus mortar.

10) Data yang sudah ditabelkan tersebut diplotkan dalam bentuk grafik seperti tampak di halaman belakang ini. 
Tabel 5. Kuat Tekan Kubus Mortar Perbandingan Dalam Volume

\begin{tabular}{|l|c|c|c|c|c|c|}
\hline Komp. & Umari & $\mathbf{7}$ hari & $\mathbf{1 4}$ hari & $\mathbf{2 1}$ hari & $\mathbf{2 8}$ hari & $\begin{array}{c}\text { Tipe } \\
\text { Mortar }\end{array}$ \\
\hline $1 \mathrm{Sm}: 1 / 2 \mathrm{Fa}$ & 18,56 & 23,35 & 26,69 & 34,85 & 41,32 & I \\
\hline $1 \mathrm{Sm}: 1 \mathrm{Fa}$ & 17,13 & 20,87 & 23,50 & 30,31 & 36,08 & II \\
\hline $1 \mathrm{Sm}: 2 \mathrm{Fa}$ & 15,75 & 17,36 & 19,95 & 25,57 & 30,51 & III \\
\hline $1 \mathrm{Sm}: 3 \mathrm{Fa}$ & 14,54 & 14,74 & 16,38 & 22,16 & 25,51 & IV \\
\hline
\end{tabular}

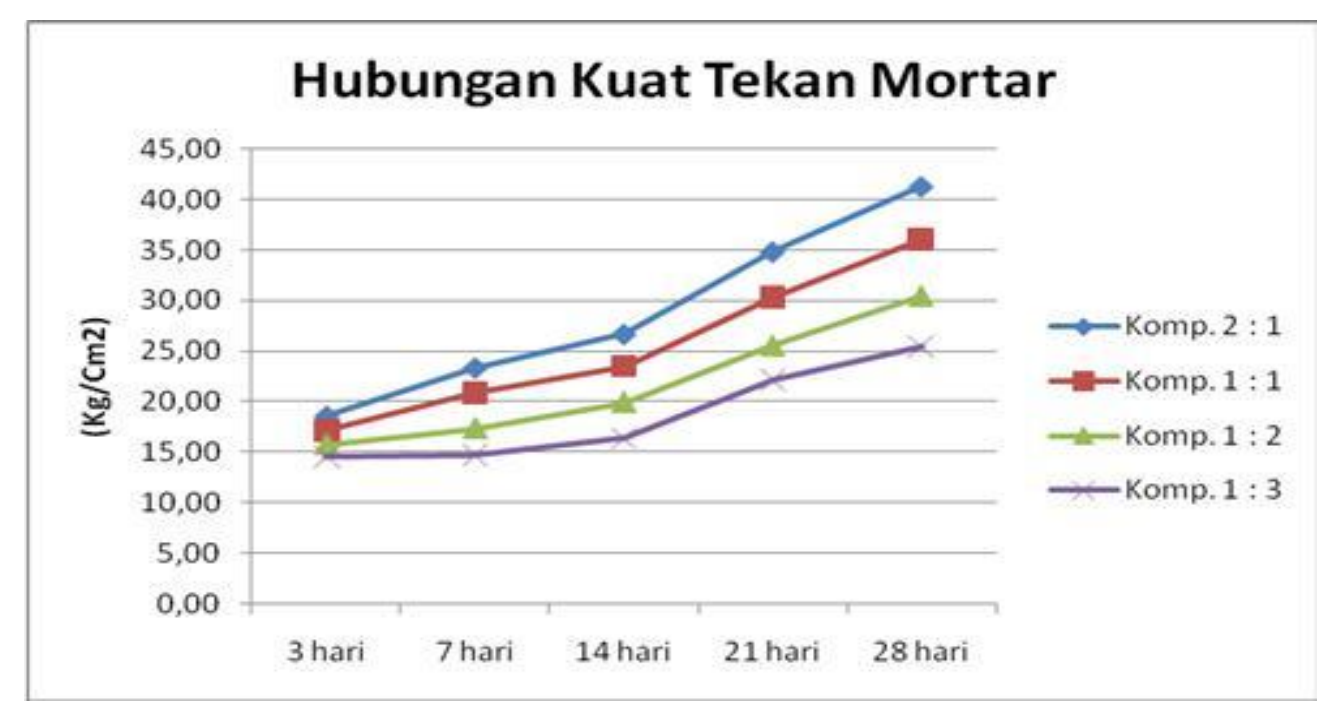

Grafik 1. Peningkatan Kuat Tekan Kubus Mortar Berdasarkan Perbandingan Volume

Tabel 6. Kuat Tekan Kubus Mortar Perbandingan Dalam Berat

\begin{tabular}{|l|c|c|c|c|c|c|}
\hline $\begin{array}{l}\text { Umur } \\
\text { Komp. }\end{array}$ & 3 hari & $\mathbf{7 ~ h a r i}$ & $\mathbf{1 4}$ hari & $\mathbf{2 1}$ hari & $\mathbf{2 8}$ hari & $\begin{array}{c}\text { Tipe } \\
\text { Mortar }\end{array}$ \\
\hline $1 \mathrm{Sm}: 1 / 2 \mathrm{Fa}$ & 23,52 & 26,26 & 35,01 & 39,19 & 53,52 & V \\
\hline $1 \mathrm{Sm}: 1 \mathrm{Fa}$ & 19,73 & 21,64 & 31,48 & 34,69 & 43,09 & VI \\
\hline $1 \mathrm{Sm}: 2 \mathrm{Fa}$ & 16,14 & 18,15 & 27,26 & 29,37 & 34,33 & VII \\
\hline $1 \mathrm{Sm}: 3 \mathrm{Fa}$ & 11,45 & 13,64 & 19,89 & 22,66 & 28,45 & VIII \\
\hline
\end{tabular}




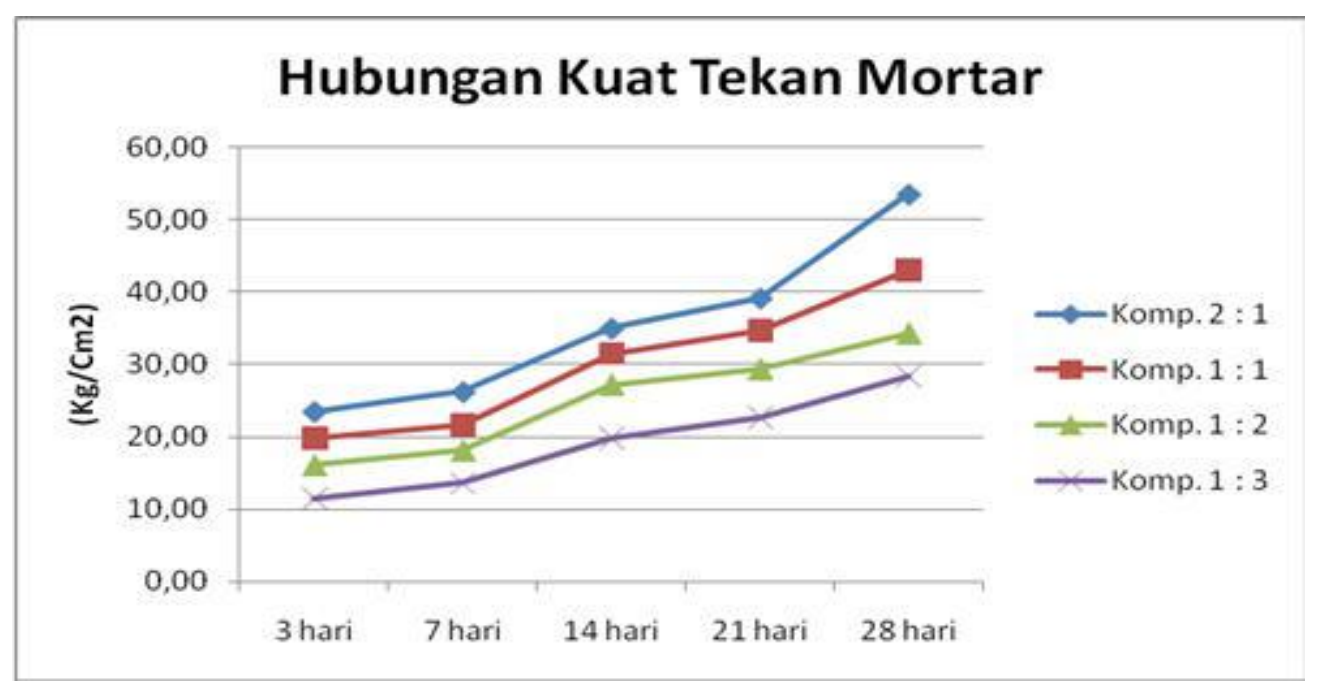

Grafik 2. Peningkatan Kuat Tekan Kubus Mortar Berdasarkan Perbandingan Berat

\section{Waktu Ikat}

Guna mengetahui waktu ikat (setting time) mortar, dilakukan langkah-langkah sebagai berikut ;

1) Diambil satu sendok semen adukan mortar, lalu diletakkan diatas permukaan keramik, kemudian diratakan.

2) Kemudian permukaan mortar itu digores dengan sendok semen.

3) Kalau bekas goresan itu menutup dengan sendirinya, berarti belum terjadi proses pengikatan dalam mortar.

4) Selanjutnya setelah satu menit permukaan mortar itu digores kembali, lalu diamati, apakah masih menutup seperti tadi, atau sudah tidak menutup kembali dengan kata lainn telah meninggalkan bekas goresan dipermukaan mortar.

5) Begitulah diulangi terus menerus dengan selang waktu 1 menit, sampai goresan meninggalkan bekas diatas permukaan mortar.

6) Waktu yang diperlukan sampai goresan meninggalkan bekas diatas permukaan mortar, disebut waktu ikat.

7) Hasil pengujian waktu ikat (setting time) mortar dapat dilihat di belakang ini.

Tabel 7. Waktu Ikat (Setting Time)

Perbandingan Dalam Volume

\begin{tabular}{|c|c|c|c|c|}
\hline Komp. & $\begin{array}{c}\mathrm{T} 1 \\
\text { (menit) }\end{array}$ & $\begin{array}{c}\mathrm{T} 2 \\
\text { (menit) }\end{array}$ & $\begin{array}{c}\mathrm{T} 3 \\
\text { (menit) }\end{array}$ & $\begin{array}{c}\text { Trata-rata } \\
\text { (menit) }\end{array}$ \\
\hline $2 \mathrm{Sm}: 1 \mathrm{Fa}$ & 1,6 & 1,8 & 2,0 & 1,8 \\
\hline $1 \mathrm{Sm}: 1 \mathrm{Fa}$ & 3,2 & 3,3 & 3,7 & 3,4 \\
\hline $1 \mathrm{Sm}: 2 \mathrm{Fa}$ & 4,5 & 3,9 & 4,6 & 4,3 \\
\hline $1 \mathrm{Sm}: 3 \mathrm{Fa}$ & 4,9 & 4,6 & 4,9 & 4,8 \\
\hline
\end{tabular}


Tabel 7. Waktu Ikat (Setting Time)

Perbandingan Dalam Berat

\begin{tabular}{|c|c|c|c|c|}
\hline Womp. & $\begin{array}{c}\text { T1 } \\
\text { (menit) }\end{array}$ & $\begin{array}{c}\text { T2 } \\
\text { (menit) }\end{array}$ & $\begin{array}{c}\text { T3 } \\
\text { (menit) }\end{array}$ & $\begin{array}{c}\text { Trata-rata } \\
\text { (menit) }\end{array}$ \\
\hline $2 \mathrm{Sm}: 1 \mathrm{Fa}$ & 2,4 & 2,2 & 2,6 & 2,4 \\
\hline $1 \mathrm{Sm}: 1 \mathrm{Fa}$ & 3,2 & 3,5 & 2,9 & 3,2 \\
\hline $1 \mathrm{Sm}: 2 \mathrm{Fa}$ & 4,4 & 4,3 & 4,2 & 4,3 \\
\hline $1 \mathrm{Sm}: 3 \mathrm{Fa}$ & 5,6 & 5,9 & 6,2 & 5,9 \\
\hline
\end{tabular}

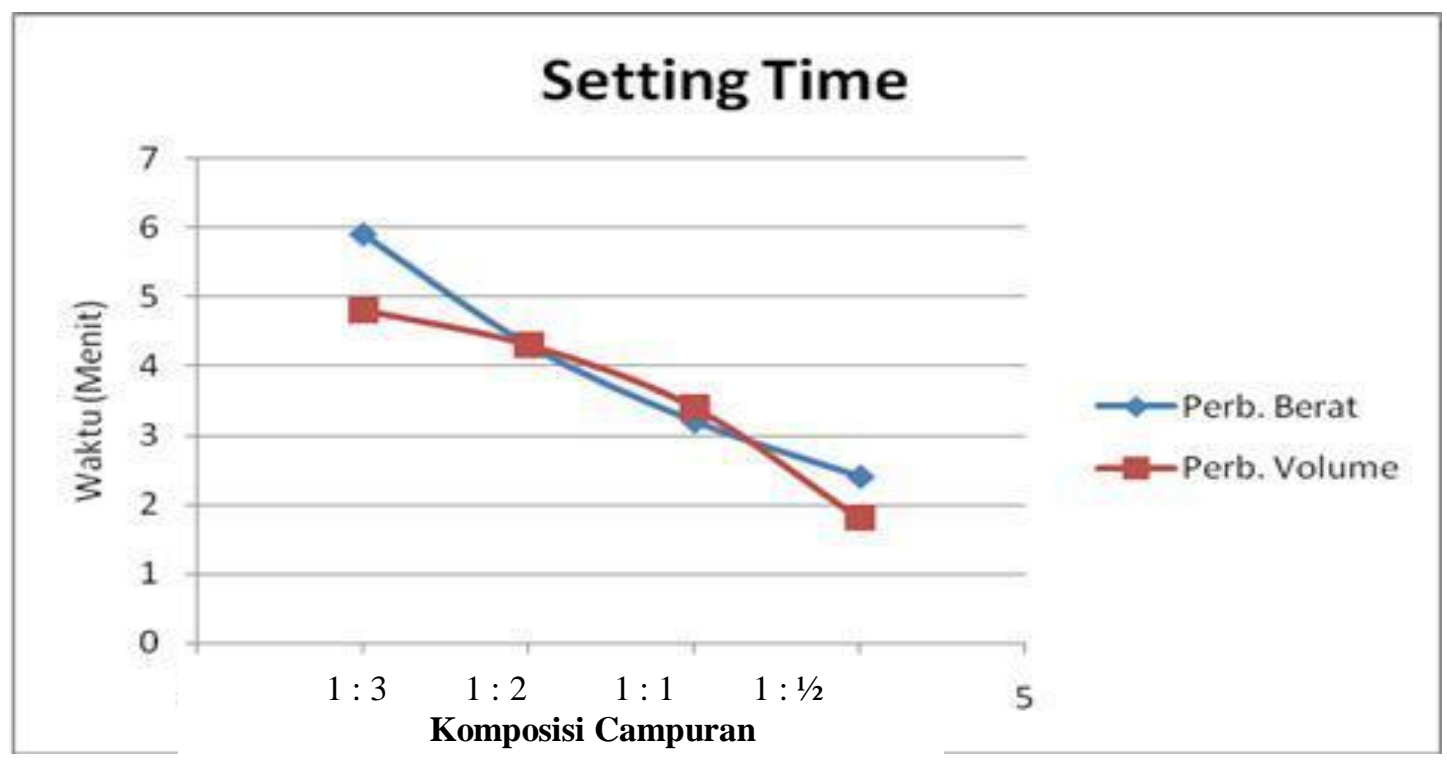

Grafik 3. Waktu Ikat Mortar Dalam Perbandingan Volume dan Berat

\section{Daya Lengket}

Guna mendapatkan nilai daya lengket antara mortar dan keramik, dilakukan pengujian pembenanan dengan langkahlangkah sebagai berikut ;

1) Pertama sekali keramik direndam dalam air selama 1 jam

2) Selanjutnya buat campuran Semen dan fly ash dalam komposisi tertentu, baik dalam perbandingan berat maupun perbandingan volume.

3) Kemudian ditambahkan air secukupnya kepada campuran semen dan fly ash tersebut, lalu diaduk sampai homogen dan plastis..

4) Selanjutnya keramik telah direndam tadi diletakan dengan permukaan licin kebawah dan permukaan kasar keatas.

5) Seterusnya diletakan kawat ikat beton dengan posisi bersilangan diatas permukaan bagian atas keramik tadi.
6) Lalu diletakkan cetakan adukan diatas permukaan keramik yang tertelentang tadi, dengan posisi ditengah-tengah, ukuran cetakan $5 \times 5 \mathrm{~cm}$ dan tebal 1,5 $\mathrm{cm}$

7) Kemudian diisikan adukan mortar didalam cetakan itu lalu diratakan dan dipadatkan.

8) Benda uji ini ditempatkan pada tempat yang aman, sampai umur 28 hari

9) Kemudian dilakukan pengujian pembebanan, dengan menggatungkan beban pada kawat ikat tadi.

10) Lalu dilakukan pencatatan beban serta waktu sampai adukan tersebut terlepas dari keramik dengan sendirinya.

11) Sudah itu dilakukan analisa Daya Lengket mortar terhadap keramik dengan rumus ; $\quad \sigma=\mathrm{P} / \mathrm{A}(\mathrm{kg} / \mathrm{cm} 2)$ 
Tabel 8. Daya Lengket Mortar Perbandingan Campuran Volume

\begin{tabular}{|c|c|c|c|c|c|}
\hline CAMPURAN & UMUR & $\begin{array}{l}\text { LUAS } \\
\text { (cm2) }\end{array}$ & $\begin{array}{l}\text { BEBAN } \\
(\mathrm{kg})\end{array}$ & $\begin{array}{l}\text { DAYA LENGKET } \\
(\mathrm{kg} / \mathrm{cm} 2)\end{array}$ & $\begin{array}{l}\text { DL rata-rata } \\
(\mathrm{kg} / \mathrm{cm} 2)\end{array}$ \\
\hline \multirow{3}{*}{$1 \mathrm{Sm}: 1 / 2 \mathrm{Fa}$} & \multirow{3}{*}{28 hari } & 42,3 & 46 & 1,087470449 & \multirow{3}{*}{1,02} \\
\hline & & 64,8 & 61,4 & 0,947530864 & \\
\hline & & 49,2 & 51,1 & 1,038617886 & \\
\hline \multirow{3}{*}{$1 \mathrm{Sm}: 1 \mathrm{Fa}$} & \multirow{3}{*}{28 hari } & 29,4 & 36,5 & 1,241496599 & \multirow{3}{*}{0,96} \\
\hline & & 58,6 & 44,16 & 0,753583618 & \\
\hline & & 58,5 & 52,3 & 0,894017094 & \\
\hline \multirow{3}{*}{$1 \mathrm{Sm}: 2 \mathrm{Fa}$} & \multirow{3}{*}{28 hari } & 28,4 & 29 & 1,021126761 & \multirow{3}{*}{0,87} \\
\hline & & 59,2 & 42,2 & 0,712837838 & \\
\hline & & 48,8 & 42,6 & 0,87295082 & \\
\hline \multirow{3}{*}{$1 \mathrm{Sm}: 3 \mathrm{Fa}$} & \multirow{3}{*}{28 hari } & 100 & 38,5 & 0,385 & \multirow{3}{*}{0,58} \\
\hline & & 81,1 & 78 & 0,961775586 & \\
\hline & & 82,7 & 32,4 & 0,391777509 & \\
\hline
\end{tabular}

Tabel 9. Daya Lengket Mortar Perbandingan Campuran Berat

\begin{tabular}{|c|c|c|c|c|c|}
\hline CAMPURAN & UMUR & $\begin{array}{l}\text { LUAS } \\
(\mathrm{cm} 2)\end{array}$ & $\begin{array}{l}\text { BEBAN } \\
(\mathrm{kg})\end{array}$ & $\begin{array}{l}\text { DAYA LENGKET } \\
(\mathrm{kg} / \mathrm{cm} 2)\end{array}$ & $\begin{array}{l}\text { DL rata-rata } \\
(\mathrm{kg} / \mathrm{cm} 2)\end{array}$ \\
\hline \multirow{3}{*}{$1 \mathrm{Sm}: 1 / 2 \mathrm{Fa}$} & \multirow{3}{*}{28 hari } & \multirow{3}{*}{25} & 27 & 1,08 & \multirow{3}{*}{0,88} \\
\hline & & & 19,4 & 0,78 & \\
\hline & & & 19,6 & 0,78 & \\
\hline \multirow{3}{*}{$1 \mathrm{Sm}: 1 \mathrm{Fa}$} & \multirow{3}{*}{28 hari } & \multirow{3}{*}{25} & 13,5 & 0,54 & \multirow{3}{*}{0,51} \\
\hline & & & 13,5 & 0,54 & \\
\hline & & & 11,5 & 0,46 & \\
\hline \multirow{3}{*}{$1 \mathrm{Sm}: 2 \mathrm{Fa}$} & \multirow{3}{*}{28 hari } & \multirow{3}{*}{25} & 8,5 & 0,34 & \multirow{3}{*}{0,30} \\
\hline & & & 6,5 & 0,26 & \\
\hline & & & 7,5 & 0,3 & \\
\hline \multirow{3}{*}{$1 \mathrm{Sm}: 3 \mathrm{Fa}$} & \multirow{3}{*}{28 hari } & \multirow{3}{*}{25} & 5,5 & 0,22 & \multirow{3}{*}{0,23} \\
\hline & & & 6,3 & 0,25 & \\
\hline & & & 5,3 & 0,212 & \\
\hline
\end{tabular}




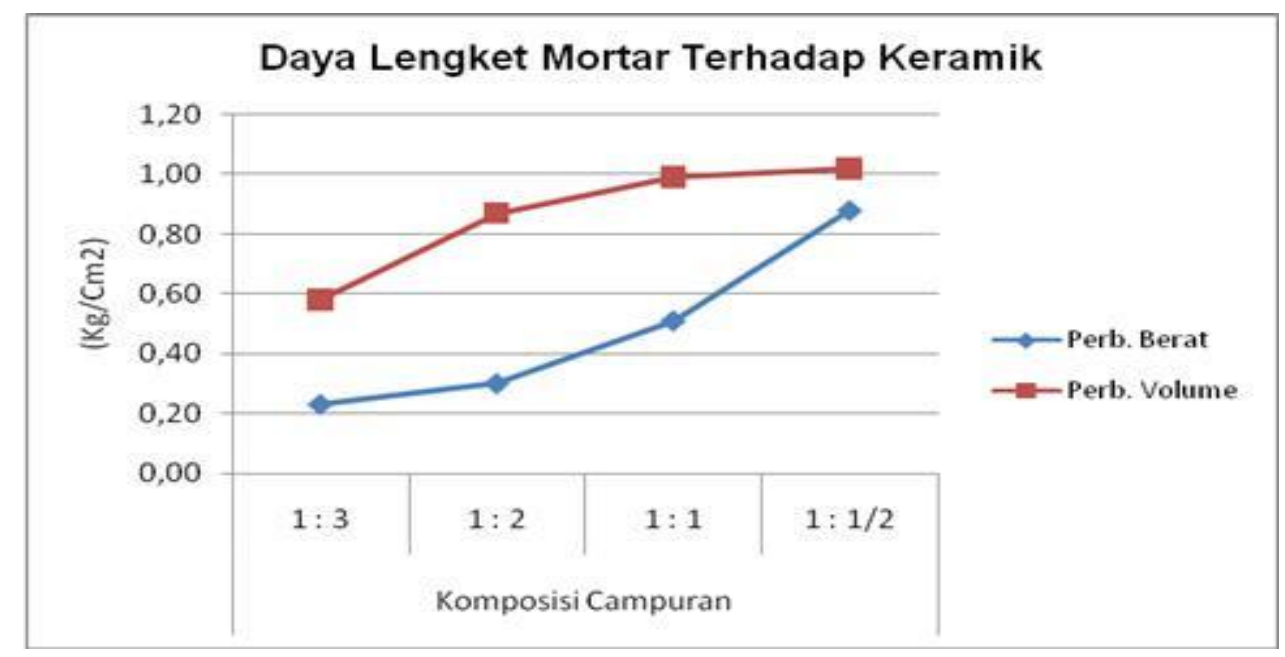

Grafik 4. Daya Lengket Mortar Terhadap Keramik

\section{Pengaruh Pemuaian dan Penyusutan}

Guna mengetahui pengaruh penyusutan dan pemuaian terhadap hubungan mortar dan keramik, dilakukan langkah-langkah sebagai berikut;

1) Siapkan keramik yang akan digunakan dalam penujian, lalu direndam dalam air selama 1 jam.

2) Siapkan adukan mortar sesuai komposisi campuran yang telah dibuat sebelumnya.

3) Letakan dua buah keramik pertama tertelentang diatas meja pengujian

4) Ambil adukan mortar diletakan diatas bagian atas keramik tadi dan diratakan setebal $1 \mathrm{~cm}$.

5) Ambil sebuah keramik lagi dan ditarok diatas adukan yang sudah diratakan tadi

6) Keramik yang sudah dipasang dengan adukan mortar tadi diletakan di tempat yang aman.

7) Setelah berumur 28 hari, lalu dilakukan pengujian penyusutan.
8) Benda uji tersebut disimpan dalam kulkas selama 2 × 24 jam

9) Sudah itu benda uji keluarkan, dan diamati apakah terjadi keretakan hubungan antara mortar dan keramik atau tidak.

10) Untuk mengetahui pengaruh pemuaian terhadap hubungan mortar dan keramik maka benda uji tersebut dimasukan kedalam oven, lalu dipanas sampai 40 derajat celcius selama $2 \times 24$ jam.

11) Sesudah itu keramik dikeluarkan dari oven, lalu diamati dengan teliti apakah terjadi keretakan hubungan antara mortar dan keramik atau tidak.

12) Kemudian dari pengamatan visual tersebut secara signicant dapat disimpulkan bahwa;

- Tidak ada pengaruh keretakan hubungan mortar dan keramik akibat penyusutan

- Tidak ada pengaruh keretakan hubungan mortar dan keramik akibat pemuaian. 
Tabel 9. Pengaruh Pemuaian dan Penyusutan Kekuatan Lengket Mortar Terhadap Keramik

\begin{tabular}{|l|c|c|c|c|c|}
\hline No & $\begin{array}{c}\text { Komposisi } \\
\text { Campuran }\end{array}$ & $\begin{array}{c}\text { Benda } \\
\text { Uji 1 }\end{array}$ & $\begin{array}{c}\text { Benda } \\
\text { Uji 2 }\end{array}$ & $\begin{array}{c}\text { Hasil } \\
\text { Akhir }\end{array}$ & KET \\
\hline Perbandingan Volume \\
\hline 1 & $2 \mathrm{Sm}: 1 \mathrm{Fa}$ & TB & TB & TB & BAIK \\
\hline 2 & $1 \mathrm{Sm}: 1 \mathrm{Fa}$ & TB & TB & TB & BAIK \\
\hline 3 & $1 \mathrm{Sm}: 2 \mathrm{Fa}$ & TB & TB & TB & BAIK \\
\hline 4 & $1 \mathrm{Sm}: 3 \mathrm{Fa}$ & B & TB & B & RETAK \\
\hline Perbandingan Berat \\
\hline 1 & $2 \mathrm{Sm}: 1 \mathrm{Fa}$ & TB & TB & TB & BAIK \\
\hline 2 & $1 \mathrm{Sm}: 1 \mathrm{Fa}$ & TB & TB & TB & BAIK \\
\hline 3 & $1 \mathrm{Sm}: 2 \mathrm{Fa}$ & TB & TB & TB & BAIK \\
\hline 4 & $1 \mathrm{Sm}: 3 \mathrm{Fa}$ & TB & TB & TB & BAIK \\
\hline $\begin{array}{l}\text { Keterangan : } \\
\text { TB Tidak Berpengaruh } \\
\text { B Berpengaruh }\end{array}$
\end{tabular}

\section{PEMBAHASAN}

\section{1). Pengujian Properties Fly Ash}

Fly ash limbah pembakaran batu bara di PLTU Sijantang, memiliki berat isi = $0,76 \mathrm{~kg} / \mathrm{cm} 3$ berarti jauh lebih ringan dari pasir sungai $\geq 1,2 \mathrm{~kg} / \mathrm{cm} 3$.

Berat Jenis (BJ) fly ash $=2,02$ ternyata lebih rendah dari BJ. Semen $=3,2$ dan kadar air fly ash $=0,29 \%$ cukup rendah. Analisa saringan menyatakan bahwa butiran fly ash sangat halus, karena semua lolos saringan nomor 200.

\section{2). Pengujian Kuat Tekan Mortar}

Untuk campuran mortar dengan perbandingan volume peningkatan kekuatan pada tahap awal agak lambat, tapi setelah berumur 14 hari peningkatan kekuatannya cukup cepat, dan bahkan pada umur 28 hari peningkatannya cukup tajam. Kekuatannya pada awalnya cukup tinggi berkisar antara $14 \mathrm{~s} / \mathrm{d} 18 \mathrm{~kg} / \mathrm{cm} 2$, namun pada akhirnya kekuatannya tidak begitu tinggi hanya berkisar sekitar $25 \mathrm{~s} / \mathrm{d} 41 \mathrm{~kg} / \mathrm{cm} 2$.

Untuk campuran mortar dengan perbandingan berat, kekuatan awalnya cukup rendah hanya berkisar $11 \mathrm{~s} / \mathrm{d} 24$ $\mathrm{kg} / \mathrm{cm} 2$, namun pada umur 28 hari, kekuatannya lebih tinggi dari perbandingan volume, yaitu mencapai $28 \mathrm{~s} / \mathrm{d} 54 \mathrm{~kg} / \mathrm{cm} 2$.

\section{3). Pengujian Waktu Ikat}

Ternyata waktu ikat (setting time) mortar berbeda tergantung komposisi campuran, dimana makin sedikit prosentase semen, maka semakin lama waktu ikatnya. Untuk perbandingan volume grafiknya terlihat melengkung ke atas, karena penurunan waktu ikat tidak linear sesuai komposisi campuran. Sedangkan untuk perbandingan berat garfiknya melengkung kebawah, karena perubahan waktu ikat tidak linear dengan perbandingan campuran.

\section{4). Daya Lengket}


Daya lengket mortar terhadap keramik, dipengaruhi oleh komposisi dan jenis perbandingan bahan mortar, makin banyak kandungan semennya maka makin tinggi daya lengketnya. Begitu juga mortar dalam perbandingan berat lebih tinggi daya lengketnya jida dibandingkan dengan perbandingan volume. Hal tersebut terbukti bahwa mortar dalam perbandingan berat, dalam pengujian pembebanannya, lebih banyak keramik yang pecah dari pada adukannya terlepas. Namun untuk mortar dalam perbandingan volume lebih banyak mortarnya terlepas dari keramik, sedangkan keramiknya tetap utuh. Untuk daya lengket mortar dengan perbandingan berat daya lengket berkisar antara $0,4 \mathrm{~s} / \mathrm{d} \quad 1,4$ $\mathrm{kg} / \mathrm{cm} 2$, sedangkan untuk mortar dengan perbandingan volume daya lengketnya berkisar antara 0,6 s/d 1,0 $\mathrm{kg} / \mathrm{cm} 2$.

\section{5). Pengaruh Pemuaian dan Penyusutan}

Secara umum pemuaian dan penyusutan tidak mempengaruhi kelekatan antara mortar dan permukaan keramik, karena dari 16 buah benda uji, hanya satu yang sedikit ada gejala keretakan pada pada mortarnya sedalam 1,5 cm. Berarti pemuaian dan penyusutan mortar hampir sama dengan pemuaian dan penyusutan keramik, hal tersebut membuktikan bahwa akibat perubahan temperatur tidak akan menyebabkan keramik terlepas dari mortarnya.

\section{Kajian Ekonomi}

Untuk Sumatera Barat saja lebih dari 200 buah toko bangunan yang menjual keramik, jika satu toko dalam seminggu rata-rata bisa menjual 25 kotak keramik, maka dalam seminggu akan terjual keramik 5.000 kotak $=5.000 \mathrm{~m} 2$. Jika satu $\mathrm{m} 2$ membutuhkan $5 \mathrm{~kg}$ semen untuk mortar pemasangannya, maka akan dibutuhkan $25.000 \mathrm{~kg}$ semen atau 500 zak semen berat
$50 \mathrm{~kg}$. Saat ini harga semen adalah Rp. 60.000, maka dalam seminggu dibutuhkan uang untuk membeli semen sebanyak Rp. 30.000.000,-

Dari hasil penelitian, diketahui bahwa mortar pemasangan keramik terdiri dari campuran 1 bagian semen dan 1 bagian fly ash, dimana fly ash dapat diambil secara gratis di lokasi PLTU Sijantang, maka akan dapat dihemat uang setengah dari Rp. 30.000.000,- = Rp. 15.000.000,- setiap minggunya. Jadi dalam satu tahun bisa dihemat uang sebesar $52 \times 15.000 .000,-=$ Rp.780.000.000,-

\section{SIMPULAN}

Selesai melakukan analisa terhadap hasil penelitian, maka dapat disimpulkan beberapa hal ;

1. Semen masih kuat pengaruhnya terhadap kuat tekan kubus mortar yang terdiri dari campuran semen + fly ash, baik mortar dalam perbandingan volume maupun perbadingan berat.

2. Peningkatan kekuatan kubus mortar untuk umur 3 hari, 7 hari, 14 hari, 21 hari dan 28 hari, baik mortar dengan perbandingan volume maupun perbandingan berat tidak linear, tetapi cenderung menguat sesuai umur benda uji.

3. Waktu ikat (setting time) mortar pada ke dua jenis perbandingan campuran ternyata berbeda, dimana makin besar angka perbandingan makin lambat waktu ikatnya.

4. Daya lengket mortar untuk mortar dalam perbandingan berat daya lengketnya lebih kuat, karena dalam pengujian pembebanan sebagian besar sampel yang pecah itu keramiknya, sedangkan mortar dalam perbandingan volume daya lengketnya lebih rendah, karena dalam uji pembebanan yang lepas itu memang ikatan adukan terhadap permukaan keramik.

5. Pengaruh pemuaian dan penyusutan terhadap kelekatan mortar dan keramik tidak significant, karena dari 16 benda 
uji, hanya 1 yang tampak secara visual keretakan hubungan mortar dan keramik.

\section{PUSTAKA}

Furguson G, (1983):" Use of Self Cementing Fly ash as a Soil Stabilisation Agent", Proc. Fly ash for Soil Improvement, ASCE Special Geotechnical Publication 36:1- 4

Henry Liu, Hilliams Burkett and Kirk Haynes, Improving Freezing and Twawing Properties of Fly Ash Bricks, 2007

Herni Khaerunisa, (2003-2007): "Toksisitas Abu Terbang dan Abu dasar Limbah PLTU Batubara yang berada di Sumatera dan Kalimantan secara Biologi”,
Puslitbang Teknologi Mineral dan Batubara

Indraratna, B., Balasubramaniam, A.S., Khan, M.J., (1995) :" Effect of Fly ash with lime and cement on the behaviour of a soft clay", Quarterly of Journal of Engineering Geology 28, pp 131-142.

Suyartono, (2004):" Hidup dengan Batubara (Dari Kebijakan hingga Pemanfaatan), No: 001/IX/2001, ISBN: 979-96649-0-X

Wardani, SPR (1999):" Behaviour of Cement Stabilized Subgrade Subject to Cyclic Loading, $\mathrm{PhD}$ Thesis, The University of New South Wales, Australia. 